\title{
ANALISIS TERJEMAHAN PENANDA KOHESI PADA NOVEL DIARY OF A WIMPY KID: CABIN FEVER KARYA JEFF KINNEY KE DALAM BAHASA INDONESIA
}

\author{
Norma Noviana ${ }^{1}$; M.R. Nababan ${ }^{2}$; Riyadi Santosa ${ }^{3}$ \\ ${ }^{1,2,3}$ Universitas Sebelas Maret, Surakarta \\ ox_novie@yahoo.co.id
}

\begin{abstract}
The research aims to (1) identify the types of lexical cohesion taxonomic markers found in the novel Diary of a Wimpy Kid: Cabin Fever and its translation, (2) explain the shift of lexical cohesion taxonomic marker types found in the novel Diary of a Wimpy Kid: Cabin Fever and its translation, (3) identify and explain translation techniques in translating lexical cohesion taxonomic markers, (4) and explain the quality of lexical cohesion taxonomic markers in the novel based on accuracy and aceptability. This descriptive qualitative research is an embeded case study, and oriented to translation product. The sources of this data consist of documents and informants (rater) selected with purpossive sampling technique. The techniques of collecting data used in this research are document analysis, questionnares, and in-depth interview. The research data are analyzed using ethnography analysis which consisting of domain, taxonomy, and componential analysis. The result shows that (1) there are ten types of lexical cohesion taxonomic markers which are categorized into hyponym, co-hyponym, conversion antonym, non-relational antonym, repetion (as a dominant cohesion type), close synonym, attitudinal synonym, consistency, cnstitution meronymy, and constitution co-meronymy, (2) there are shift in translating the lexical cohesion taxonomic marker types, (3) the translation techniques found in this research are established equivalent (as a dominant technique), variation, reduction, amplification, transposition, modulation, description, discursive creation, pure borrowing and naturalized borrowing. (4) The techniques applied to translation gives the good impact to quality of translation from accuracy and acceptability, supported with the high average score of quality.
\end{abstract}

Keywords : lexical cohesion taxonomic, sistemic fungtional, shift, translation techniques, translation quality

\section{Pendahuluan}

Kohesi merupakan permasalahan yang sangat menantang dalam penerjemahan karena setiap bahasa memiliki penanda kohesi sendiri dan memiliki keunikan dalam pemakaian penanda kohesi itu (Schiller, 2006). Kohesi menunjuk pada relasi yang tampak dalam sebuah wacana atau teks (Verschueren, 1999 dalam Supana, 2012). Relasi kohesi sebagian diungkapkan melalui tata bahasa dan sebagian diungkapkan melalui kosa kata. Oleh karena itu dikenal adanya kohesi gramatikal dan kohesi leksikal 
(Halliday \& Hasan, 1976). Aspek-aspek kebahasaan yang menghubungkan antar bagian teks dan yang membuat teks menjadi kohesif disebut penanda kohesi. Berkaitan dengan adanya kohesi gramatikal dan kohesi leksikal tersebut, penanda kohesi juga dapat dipilahkan menjadi penanda kohesi gramatikal dan penanda kohesi leksikal (Supana, 2012).

Penelitian ini secara garis besar membahas tentang penanda kohesi khususnya penanda kohesi leksikal taksonomi, novel anak-anak yang berjudul Diary of a Wimpy Kid: Cabin Fever karya Jeff Kinney dan terjemahannya dalam bahasa Indonesia, serta analisis wacana berdasarkan SLF sebagai pendekatan yang digunakan. Penelitian ini mengkaji penanda kohesi leksikal taksonomi yang terdapat pada novel anak-anak. Novel jenis ini menarik untuk dikaji karena selain belum ada yang mengkaji novel jenis ini pada penelitian-penelitian sebelumnya, untuk menerjemahkan novel jenis ini, penerjemah harus menyesuaikan kata-kata yang digunakan agar bisa diterima dan dipahami oleh pembaca yaitu anak-anak. Seperti misalnya pada novel anak-anak, pemilihan kata lebih sederhana dibanding dengan novel dewasa. Hal tersebut dikarenakan logika anak masih sangat sederhana sehingga kemampuan anak untuk memahami isi sebuah novel juga masih sangat sederhana jika dibandingkan dengan kemampuan logika orang dewasa sehingga jenis kohesi leksikal taksonominyapun diharapkan akan berbeda juga.

Di dalam novel tersebut, banyak dijumpai penanda kohesi khususnya kohesi leksikal taksonomi seperti yang dikembangkan Martin (1992) yang dijelaskan pula oleh Santosa (2003) dengan modifikasinya. Pada penelitian ini akan diidentifikasi dan dianalisis tentang jenis kohesi leksikal taksonomi berdasarkan pengklasifikasian Martin dan modifikasi dari Santosa tersebut. Pengklasifikasian tersebut dapat dijelaskan sebagai berikut; kohesi leksikal taksonomi berdasarkan hubungannya, dibagi menjadi dua yaitu kohesi leksikal taksonomi dan non-taksonomi yang dibagi lagi lebih lanjut.

Kohesi Taksonomis terdiri dari superordinasi dan komposisi. Superordinasi terdiri dari inklusi dan similariti. Inklusi meliputi hiponimi dan co-hiponimi. Similariti terdiri dari antonimi, repetisi, dan sinonimi. Antonimi dibagi lagi menjadi dua yaitu konversi dan non-relasional. Sinonimi dibagi menjadi dua juga yaitu dekat dan atitudinal. Sedangkan komposisi bisa bersifat kolektifitas, konsistensi, dan kontituensi. 
Kontituensi sendiri terdiri dari meronimi dan co-meronimi (Santosa, 2003). Salah satu contoh adalah sebagai berikut.

Bsu : I was really confused, but on the walk home I realized what must've happened.

Bsa : Aku benar-benar bingung, tapi dalam perjalanan pulang, aku menyadari kejadian yang sebenarnya.

Pada data tersebut, kata $I$, yang pada Bsa diterjemahkan menjadi $A k u$, pada klausa kedua merupakan repetisi dari I pada kalusa pertama. Hal tersebut disebabkan kedua kata $I$ (aku) mengacu pada orang yang sama yaitu tokoh utama pada novel Diary of a wimpy Kid: Cabin Fever dan terjemahannya, Greg. Kata tersebut diulang untuk menjaga kepaduan kalimat tersebut karena memerankan fungsi sebagai penenda kohesi leksikal taksonomi agar pada kaluasa pertama dan kalusa kedua pada kalimat diatas membentuk suatu kepaduan yang baik dan utuh. Sama halnya pada data 22 di atas, data 20 ini juga merupakan penanda kohesi leksikal taksonomi yang tidak bergeser karena antara Bsu dan Bsa nya penanda kohesi leksikal taksonominya adalah sama yaitu berjenis repetisi.

Selain tentang jenis kohesi seperti yang dipaparkan di atas, pada penelitian ini juga diteliti tentang bagaimana pergeseran jenis kohesi leksikal taksonomi yang ada pada Novel Diary of a Wimpy Kid: Cabin Fever ini. contoh dari pergeseran tersebut seperti di bawah ini.

Bsu : Kids whose families don't celebrate Christmas are lucky because they don't have to stress out whenever they do something wrong at this time of year.

Bsa : Anak-anak yang keluarganya tidak merayakan Natal beruntung karena tidak perlu merasa tertekan kapanpun mereka melakukan kesalahan pada akhir tahun seperti ini.

Pada data di atas, contoh perubahan dari repetisi menjadi non-kohesi LT ditunjukkan dengan adanya pengulangan kata they pada Bsu namun tidak ada pengulangan mereka yang merupakan terjemahan dari they pada Bsa nya sehingga dikatakan Bsa mengandung penanda kohesi leksika taksonomi jenis repetisi sementara Bsa tidak. Hal ini disebabkan adanya penghilangan suatu unsur yang terdapat pada Bsu dan dihilangkan pada Bsa, yaitu kata they pada klausa kedua. Namun demikian penghilangan tersebut berterima karena tidak menyebabkan berubahnya pesan dalam teks tersebut. Penghilangan dilakukan untuk efisiensi kalimat. Bahasa sasaran 
membolehkan dua atau lebih klausa yang memiliki subjek yang sama namun kata kerjanya berbeda hanya menuliskan satu subjek saja. Berbeda dengan tata Bahasa Inggris dimana kata kerja akan didahului oleh subjek dalam kalimat yang berbentuk pernyataan.

Penelitian ini juga akan menganalisis tentang teknik penerjemahan berdasarkan teori dari Molina dan Albir (2002). Menurut mereka teknik penerjemahan dapat diklasifikasikan ke dalam 18 macam teknik, yaitu adaptasi (adaptation), amplikasi (amplification), pinjaman (borrowing), kalke (calque), kompensasi (compensation), deskripsi (description), kreasi diskursif (discursive creation), kesepadanan lazim (established equivalent), generalisasi (generalization), amplifikasi linguistik (linguistic amplification), kompresi linguistik (linguistic compression), penerjemahan harfiah (literal translation), modulasi (modulation), partikularisasi (particularization), reduksi (reduction), substitusi (substitution), transposisi (transposition), dan variasi (variation). Salah satu contoh dari penggunaan teknik penerjemahan adalah sebagai berikut.

Bsu : So I'm sure Dad is ready to ship me off to juvenile detention the first chance he gets.

In fact, if he's home when the police come, he'll probably hand me over into their custody without batting an eye.

Bsa : Jadi, aku yakin Dad siap untuk mengirimku ke penjara anak-anak pada kesempatan pertama yang dia dapatkan.

Sebenarnya, jika Dad ada di rumah saat polisi datang, dia mungkin akan langsung menyerahkan aku kepada mereka tanpa mengedipkan mata.

Pada data di atas, terdapat kata he yang berfungsi sebagai penanda kohesi leksikal taksonomi jenis repetisi. Dikatakan repetisi karena pada Bsu penggunaan kata he diulang pada kalimat berikutnya. Namun begitu diterjemahkan ke dalam bahasa Indonesia, repetisi tersebut tidak ditemukan. Kata he pada kalimat pertama diterjemahkan menjadi dia. Terjemahan semacam ini menggunakan teknik kesepadanan lazim. Sementara itu, untuk kata he pada kalimat berikutnya diterjemahkan menjadi Dad. Penerjemahan kata he menjadi Dad menggunakan teknik transposisi, yaitu teknik mengubah atau menggeser susunan gramatikal antara bahasa sumber dengan bahasa sasaran.

Dan yang terakhir, pada penelitian ini juga akan dilihat bagaimana kualitas terjemahan dari penanda kohesi leksikal taksonomi berdasarkan teori Nababan dkk 
(2012) yang difokuskan pada aspek keakuratan dan keberterimaan. Berikut adalah contoh dari aspek keakuratan dan keberterimaan:

Data yang akurat.

Bsu : When I woke up this morning, I thought maybe everything that happened last night was just a bad dream.

Bsa : Saat terbangun pagi ini, kupikir mungkin semua yang terjadi tadi malam hanya sebuah mimpi buruk.

Pada data di atas, ketiga rater sepakat memberi nilai 3. Hal ini menunjukkan bahwa data di atas akurat. Penanda kohesi leksikal taksonomi this morning yang diterjemahkan menjadi pagi ini dan last night yang diterjemahkan menjadi tadi malam sesuai dengan makna leksikalnya dengan konteks novel Diary of a Wimpy Kid : Cabin Fever. Makna yang terkandung dalam bahasa sumber tersampaikan dengan tepat dalam Bsa.

Data yang berterima.

Bsu : I don't know if the person who called out was a parent or a police officer or what, but I just hope they didn't recognize us.

Bsa : Aku tak tahu apakah orang yang berteriak itu orangtua atau polisi atau apa, tapi aku hanya berharap mereka tidak mengenali kami.

Ketiga rater memberikan nilai 3 pada data ini, sehingga data tersebut merupakan terjemahan yang berterima. Penanda kohesi yang berbentuk kata ganti orang pertama yaitu I diterjemahakan menjadi aku baik pada klausa pertama maupun pada klausa ketiga. Terjemahan tersebut menggunakan teknik variasi sehingga $I$ diterjemahkan menjadi $a k u$ yang merupakan variasi dari saya. Aku yang digunakan pada novel sudah sangat sesuai dengan kaidah bahasa Indonesia, dimana pada novel ini bahasa yang digunakan bukanlah bahasa resmi, sehingga penggunaan aku lebih mudah diterima pembaca. Hasil penerjemahan yang berterima akan membuat pembaca menjadi tidak menyadari bahwa ini adalah karya terjemahan.

\section{Teori dan Metodologi Penelitian}

Penelitian ini merupakan sebuah penelitian deskriptif kualitatif dengan design studi kasus terpancang dan berorientasi pada produk terjemahan. Penelitian ini merupakan studi kasus tunggal karena sasarannya menganalisa penanda kohesi leksikal 
taksonomi yang berupa kata ataupun frasa, dan pergeseran jenis kohesinya yang terjadi pada novel terjemahannya Diary si Bocah Tengil : Demam Kabin.

Data yang dikumpulkan, dikelompokkan, dianalisis dan diinterpretasikan dalam penelitian ini adalah terjemahan penanda kohesi leksikal taksonomi baik yang berupa kata ataupun frasa yang terdapat pada novel terjemahan Diary si Bocah Tengil : Demam Kabin. Dalam penelitian ini dipilih dan dikumpulkan berdasarkan pendekatan penerjemahan dan pendekatan analisis wacana berdasarkan LSF. Dengan pendekatan penerjemahan dapat diketahui teknik-teknik penerjemahan yang digunakan dalam menerjemahkan penanda kohesi leksikal taksonomi yang terdapat pada novel terjemahan Diary si Bocah Tengil : Demam Kabin. Selain itu dengan pendekatan ini, kualitas terjemahan penanda kohesi leksikal taksonomi dalam novel tersebut dapat diukur menggunakan aspek keakuratan dan keberterimaan. Lebih lanjut, pendekatan analisis wacana berdasarkan LSF digunakan untuk mengetahui jenis-jenis kohesi leksikal taksonomi yang terdapat pada novel Diary of A Wimpy Kids: Cabin Fever karya Jeff Kinney dan terjemahannya, Diary si Bocah Tengil: Demam Kabin. Selain itu dengan pendekatan analisis wacana ini juga dapat digunakan untuk mengetahui dan menganalisa pergeseran jenis penanda kohesi leksikal taksonomi yang ada.

Dalam penelitian ini, purposive sampling atau disebut juga teknik criterion-based sampling digunakan sebagai teknik sampling dalam pengambilan data. Sementara itu, untuk pengecekan validitas datanya menggunakan teknik triangulasi. Dalam mengumpulkan data, penelitian ini menggunakan analisis isi, kuesioner, dan wawancara. Kuisioner diberikan kepada rater untuk mendapatkan penilaian kualitas hasil terjemahan dan wawancara untuk mendapatkan informasi yang lebih mendalam.

\section{Hasil Penelitian dan Pembahasan}

Dalam analisis ini, jenis kohesi khususnya kohesi leksikal taksonomi didasarkan pada pengklasifikasian Martin (1992) dengan modifikasi dari Santosa (2003). Penelitian ini dilakukan dengan menganalisis novel Diary of a Wimpy Kid: Cabin Fever dan terjemahannya dalam Bahasa Indonesia, Diary si Bocah Tengil : Demam Kabin. Pada penelitian ini ditemukan 371 data yang kemudian dikelompokan menjadi 2 kelompok yaitu data yang tidak bergeser (sebanyak 284 data atau 76,57\%), atau dalam arti lain antara Bsu dan Bsa nya berjenis kohesi sama, dan data yang bergeser (sebanyak 87 data 
atau 23.45\%), yaitu jenis kohesi leksikal taksonomi pada Bsu tidak sama dengan Bsa. Berdasarkan jenis kohesinya, 371 data tersebut, tujuh dari sepuluh jenis penanada kohesi leksikal taksonomi tersebut termasuk dalam kategori superordinasi, yaitu hiponimi (10 data / 2.7\%), ko-hiponimi (6 data / 1.62\%), antonimi konversi (9 data / $2.43 \%$ ), antonimi non-relasional (4 data / 1.08\%), repetisi (253 data / 68.19\%), sinonimi dekat (15 data / 4.04\%), dan sinonimi atitudinal (4 data / 1.08\%). Sisanya termasuk ke dalam kategori komposisi, yaitu konsistensi (1 data / 0.27\%), konstitusi meronimi (29 data atau 7.82\%), dan konstitusi ko-meronimi (13 data atau 3.50\%). Selain itu terdapat satu kategori diluar kelompok superordinasi dan komposisi yaitu non-kohesi LT dimana dalam penelitian ini ditemukan data sebanyak 27 data atau $7.28 \%$, sehingga dari data tersebut dapat diketahui bahwa jenis kohesi repetisi merupakan jenis kohesi leksikal yang mendominasi temuan pada penelitian ini.

Sementara itu, untuk terdapat pergeseran jenis kohesi leksikal taksonomi yang terjadi dalam terjemahan penanda kohesi leksikal taksonomi yang ditemukan pada novel Diary of a Wimpy Kid: Cabin Fever. Pergeseran yang dimaksud pada penelitian ini adalah perubahan jenis penanda kohesi leksikal taksonomi pada Bsu dan Bsa. Dari bagian sebelumnya diketahui bahwa terdapat 87 data atau $23,45 \%$ dari data keseluruhan, mengalami pergeseran jenis kohesinya. Jika dilihat hanya dari data yang bergeser berarti 87 data atau 100\%. Pergeseran jenis kohesi tersebut terdiri dari 12 macam pergeseran. Jika diurutkan mulai dari yang terbanyak yaitu repetisi menjadi nonkohesi LT sebanyak 43 data, atau $49.42 \% \%$ dari keseluruhan data yang bergeser, kemudian Non-kohesi LT - repetisi (22 data / 25.29\%), Sinonimi dekat - repetisi (10 data / $11.49 \%$ ), repetisi - sinonimi dekat (3 data / 3.45\%), non-kohesi LT- sinonimi dekat ( 2 data / 2.30\%), dan masing-masing hanya terdapat satu data atau 1,15\% dari data keseluruhan yang bergeser yaitu hiponimi - meronimi, antonimi konversi - nonkohesi LT, Sinonimi atitudinal - repetisi, ko-meronimi - non-kohesi LT, dan yang terakhir non-kohesi LT - meronimi.

Seperti yang dijelaskan di atas, pergeseran dari repetisi menjadi non-kohesi LT frekuensi kemunculannya paling banyak. Sementara itu pergeseran dari Non-kohesi LT menjadi repetisi juga menduduki urutan ke dua terbanyak. Dengan kata lain, pada teks bahasa Indonesia cenderung menghilangkan repetisi jika dibanding dengan teks bahasa Inggris. Hal tersebut dapat disebabkan perbedaan tata bahasa Indonesia dan bahasa 
Inggris. Dalam penelitian ini, kasus yang banyak terjadi adalah menghilangkan salah satu subjek yang terdapat pada satu kalimat yang mengandung subjek lebih dari satu padahal merefer pada orang / benda yang sama. Hal ini diperbolehkan dalam bahasa Indonesia, bahkan kalimat dengan menggunakan satu subjek meskipun menjelaskan dua kejadian dinilai lebih efisien. Sementara pada bahasa Inggris satu subjek untuk satu kata kerja / kejadian.

Analisis teknik penerjemahan untuk menerjemahkan penanda kohesi leksikal taksonomi dilakukan setelah semua data dianalisis jenis dan pergeseran jenis kohesinya. Analisis teknik penerjemahan ini berdasarkan pada teori teknik penerjemahan Molina dan Albir (2002). Analisis data yang dilakukan hanya pada setiap jenis data yang mengandung penanda kohesi leksikal taksonomi khususnya yang berbentuk kata / frasa benda yang didalamnya terdapat pronomina. Total data yang dianalisis teknik penerjemahannya sebanyak 371 data yang kemudian dikelompokkan ke dalam varianvarian yang ada yaitu varian tunggal (243 data / 65.50\%), varian kuplet (115 data / $31 \%$ ), varian triplet (12 data / 3.23\%), dan varian kuartet (1 data / 0.27\%). Total teknik yang digunakan dalam menerjemahkan data penelitian ini ada 11 jenis teknik. Jika berdasarkan frekuensi kemunculan teknik penerjemahan, maka jumlah total adalah 479 yang terdiri dari Amplifikasi 18 kali (3.76\%), peminjaman murni 60 kali (12.53\%), kesepadanan lazim 203 kali (42.38\%), variasi 106 kali (22.13\%), reduksi 26 kali (5.42\%), peminjaman ternaturalisasi 26 kali (5.42\%), modulasi 12 kali (2.51\%), transposisi 25 kali (5.22\%), kreasi diskursif 1 kali (0.21\%), adaptasi 1 kali (0.21\%) dan deskripsi 1 kali $(0.21 \%)$.

Penilaian kualitas terjemahan digunakan untuk mengetahui mutu hasil terjemahan dari sebuah teks. Menurut Nababan (2008), kualitas terjemahan melibatkan tiga hal, yaitu ketepatan pengalihan pesan, ketepatan pengungkapan pesan, dan kealamiahan bahasa terjemahan. Dalam penelitian ini, untuk mengukur ketepatan pengalihan pesan (aspek keakuratan) dan ketepatan pengungkapan pesan (aspek keberterimaan) dinilai oleh masing-masing tiga Rater. Penilaian kealamiahan bahasa terjemahan atau penilaian aspek keterbacaan tidak dilakukan dalam penelitian ini. Hal ini disebabkan penanda kohesi leksikal taksonomi pada penilaian ini di fokuskan hanya yang berbantuk kata, kelompok kata atau frasa. 
Dari penelitian ini didapatkan hasil akhir untuk tingkat keakuratan diketahui sebanyak 355 data $(95,69 \%)$ termasuk akurat, dan 16 data $(4,31 \%)$ dinilai kurang akurat. Sedangkan tingkat keberterimaan diketahui sebanyak 329 data (88.68\%) berterima, 21 data $(5.66 \%)$ dinilai kurang berterima, dan 21 data (5.66\%) tidak berterima. Dari penilaian tersebut, maka nilai rata-rata kualitas terjemahan penanda kohesi leksikal taksonomi dalam novel Diary of a Wimpy Kid: Cabin Fever dan terjemahannya dinyatakan berkualitas tinggi, yaitu dengan nilai akhir 2,89.

\section{Simpulan}

Setelah hasil penelitian dikumpulkan dan dilakukan pembahasan, maka dapat ditarik simpulan bahwa pada setiap generic structure dari novel ini terdapat penanda jenis leksikal taksonomi, yang terbagi ke dalam sepuluh jenis dengan jumlah frekuensi yang berbeda-beda. kesepuluh jenis tersebut adalah hiponimi, ko-hiponimi, antonimi konversi, antonimi non-relasional, repetisi, sinonimi dekat, sinonimi atitudinal, konsistensi, meronimi, dan terakhir ko-meronimi. Dari keseluruhan data jenis penanda kohesi leksikal taksonomi yang paling sering muncul adalah repetisi. Repetisi merupakan pengulangan realitas yang sama dengan leksis yang sama pula. Sedangkan yang paling sedikit frekuensi kemunculannya adalah konsistensi yang merupakan jenis penanda kohesi yang menyatakan hubungan antara benda dan materialnya. Hal ini disebabkan oleh sumber data yang digunakan pada penelitian ini adalah novel yang ditujukan untuk pembaca usia anak-anak dan remaja, sehingga kosakata yang digunakan lebih sederhana dibanding novel dewasa sehingga banyak ditemukan pengulangan kata atau repetisi. Sementara itu konsistensi menjadi jenis kohesi leksikal paling jarang mungkin juga dikarenan objek dari penelitian ini adalah novel yang bergenre narartive, bukan prosedure text.

Dalam terjemahan data penanda kohesi leksikal taksonomi dari bahasa Inggris ke bahasa Indonesia ditemukan pergeseran jenis kohesi leksikal taksonomi. Pergeseran tersebut bisa berupa pergeseran jenis penanda kohesi taksonomi yang satu menjadi jenis penanda kohesi leksikal taksonomi yang lain, misalnya repetisi menjadi sinonimi dekat, atau juga dari salah satu jenis penanda kohesi leksikal taksonomi menjadi kata / frasa yang bukan penanda kohesi leksikal taksonomi atau dalam penelitian ini dimasukkan pada kategori Non-kohesi LT atau bisa juga dari kata / frasa yang bukan penanda kohesi 
leksikal taksonomi menjadi salah satu penanda kohesi leksikal taksonomi misalnya repetisi. Kategori non-kohesi LT tersebut menyebabkan penambahan dan penguranagan penanda kohesi leksikal taksonomi yang ada. Pergeseran jenis kohesi ini banyak disebabkan oleh pergeseran makna dalam kata / frasa yang berfungsi sebagai penanda kohesi leksikal taksonomi. Namun demikian, dari data keseluruhan, yang mengalami pergeseran hanyalah $23,18 \%$. Hal itu berarti bahwa data yang tidak mengalami pergeseran masih lebih dominan dari pada yang bergeser.

Sementara itu, penerapan varian teknik penerjemahan untuk penanda kohesi leksikal taksonomi ini meliputi empat varian teknik yaitu varian tunggal, kuplet, triplet dan kuartet. Sedangkan untuk teknik penerjemahan yang ditemukan dalam penelitian ini yaitu: kesepadanan lazim, variasi, peminjaman murni, peminjaman ternaturalisasi, reduksi, transposisi, amplifikasi, modulasi, kreasi diskursif dan deskripsi. Penerapan varian terbanyak pada penelitian ini yaitu menggunakan varian tunggal, sementara teknik penerjemahan yang peling sering dipakai yaitu teknik kesepadanan lazim. Penelitian ini juga menunjukkan bahwa dari penerapan teknik-teknik tersebut mengakhibatkan sebagian terjemahan penanda kohesi leksikal taksonomi ada yang bergeser, baik bergeser menjadi jenis penanda kohesi leksikal taksonomi lain, misalnya dari sinonimi dekat bergeser menjadi repetisi, ataupun bergeser menjadi kata-kata atau frasa biasa, tidak berfungsi sebagai penanda kohesi leksikal taksonomi.

Pada penilaian kualitas terjemahan, khususnya untuk aspek keakuratan, kualitas terjemahan termasuk dalam kategori yang akurat. Hal ini disebabkan oleh penerapan teknik kesepadanan lazim yang mendominasi terjemahan pada penelitian ini. Selain itu teknik peminjaman baik peminjaman murni ataupun peminjaman ternaturalisasi juga banyak digunakan, terutama ketika menerjemahkan pelaku-pelaku pada novel ini, seperti cenderung mempertahankan istilah Mom dan Dad. Meski tidak berterima, namun pemakaian istilah-istilah tersebut dinilai akurat. Sementara itu, dari aspek keberterimaan, penanda kohesi leksikal taksonomi jika dilihat dari hasil rata-rata termasuk dalam kategori berterima. Meski nilainya tidak sebanyak keakuratan, namun nilai keberterimaan tetaplah pada rentang berterima. Hal ini disebabkan banyaknya pemakaian teknik peminjaman, khususnya peminjaman murni untuk menerjemahkan istilah Mom dan Dad yang jika diterjemahkan menjadi Mama atau Ibu dan Papa atau Ayah dirasa akan lebih berterima. Pemakaian teknik reduksi yang kerap dipakai ketika 
menerjemahkan I yang muncul lebih dari satu kali juga menyebabkan penanda kohesi leksikal taksonomi dalam penelitian ini berterima. Meski terdapat reduksi, namun tidak ada distorsi makna pada klausa yang ditempati. Teknik reduksi tersebut digunakan dengan alasan agar lebih efektif ketika diterjemahkan ke dalam bahasa Indonesia. Secara keseluruhan dapat diketahui, rata-rata kualitas terjemahan penanda kohesi leksikal taksonomi dalam novel Diary of a Wimpy Kid: Cabin Fever dan terjemahannya dinyatakan berkualitas tinggi.

Dalam hubungan kelima aspek tersebut, pada akhirnya dapat disimpulkan bahwa jenis penanda kohesi leksikal taksonomi repetisi merupakan jenis kohesi yang mendominasi semua bagian struktur cerita (generic structure) baik pada bagian orientation, complication, evaluation, maupun resolution. Hal ini disebabkan jenis dokumen yang diteliti adalah novel khususnya novel anak-anak, dimana repetisi dinilai cara yang efektif untuk mengungkapkan makna dan pesan cerita dibanding dengan jenis kohesi yang lain. Sementara itu berkaitan dengan varian teknik, secara umum didominasi varian tunggal. Hal ini disebabkan penanda kohesi leksikal taksonomi sebagian besar berbentuk kata sehingga hanya butuh satu teknik untuk menerjemahkan, dan penggunaan satu teknik itu masuk dalam kategori varian tunggal. Sedangkan untuk teknik, teknik yang paling sering digunakan adalah teknik kesepadanan lazim. Teknik ini muncul baik pada varian tunggal, kuplet, triplet, maupun kuartet. Hal ini dapat disebabkan dalam menerjemahkan penanda kohesi leksikal taksonomi pada novel tetaplah membutuhkan konteks, dan teknik yang menggunakan konteks dalam penerjemahannya adalah teknik kesepadanan lazim, sehingga wajar jika teknik ini sering digunakan dalam penerjemahan penanda kohesi leksikal taksonomi dalam penelitian ini. Meski demikian, penggunaan teknik kesepadanan lazim bukanlah satusatunya teknik yang digunakan pada penelitian ini. ada beberapa teknik yang juga digunakan. Teknik-teknik tersebut menjadikan jenis penanda kohesi leksikal taksonomi mengalami pergeseran dan ada juga yang tidak mengalami pergeseran. Dalam penelitian ini, jenis kohesi leksikal taksonomi yang tidak bergeser lebih banyak ditemukan. Hal ini disebabkan penggunaan teknik kesepadanan lazim yang mampu menerjemahkan makna dari Bsu ke Bsa. Selain itu penggunaan teknik peminjaman juga sering menghasilkan jenis kohesi leksikal taksonomi yang sama antara Bsu dan Bsa nya, karena teknik ini sering digunakan pada penanda kohesi leksikal taksonomi repetisi. Pergeseran jenis 
kohesi leksikal taksonomi yang tidak bergeser tersebut menyebabkan kualitas terjemahan dinilai akurat dan berterima. Hal tersebut disebabkan jenis kohesi leksikal taksonomi yang tidak bergeser berarti secara umum makna kata dan frasa yang berfungsi sebagai penanda kohesi leksikal taksonomi dalam bahasa sumber sudah dialihkan secara akurat ke dalam bahasa sasaran dan tidak ada distorsi makna. Selain itu terjemahan novel ini terasa alamiah, istilah yang digunakan secara umum sudah lazim dan akrab bagi pembaca, serta kata dan frasa yang digunakan sebagian besar sudah sesuai dengan kaidah bahasa Indonesia, sebagai bahasa sasaran.

\section{Referensi}

Baker, M. (1992). In other words: A course book on translation. London: Routledge.

Catford, J. C. (1974). A linguistic theory of translation: An essay in applied linguistics. London: Oxford University Press.

Halliday, M. A. K., \& Hasan, R. (1976). Cohesion in English. London: Longman.

Halliday, M. A. K., \& Matthiessen, C. (2004). An introduction to functional grammar. London: Arnold.

Kinney, J. (2011). Diary of a wimpy kid: cabin fever. New York: Amulet Books. (2013). Diary si bocah tengil : demam kabin (edisi terjemahan oleh Maria Lubis). Jakarta: Atria.

Larson, M. L. (1984). Meaning - based translation: a guide to cross-language equivalence. Boston: University Press of America.

Machali, R. (2000). Pedoman bagi penerjemah. Jakarta: PT Grasindo.

Martin, J. R. (1992). English text: system and structure. Philadelphia / Amsterdam: John Benjamins Publishing Company.

Moleong, L. J. (2010). Metodologi penelitian kualitatif. Bandung: PT Remaja Rosdakarya.

Molina \& Albir, H. (2002). Translation techniques revisited: A dynamic and functionalist approach. University Autonama de Barcelona, Barcelona, Spain: Meta Jurnal XLVII.

Nababan, M. R. (2008). Teori menerjemah bahasa Inggris. Yogyakarta: Pustaka Pelajar. 
Nababan, M. R., Nuraeni, A., \& Sumardiono. (2012). Pengembangan model kualitas terjemahan. Kajian linguistik dan sastra.Vol.24, No.1.

Newmark, P. (1988). A textbook of translation. London: Prentice Hall.

Santosa, R. (2003). Semiotika sosial. Surabaya: Eureka.

Santosa, R. (2011). Logika wacana: analisis hubungan konjungtif dengan pendekatan linguistik sistemik fungsional. Surakarta: UNS Press.

Santosa, R. (2012). Metode penelitian kualitatif kebahasaan. Surakarta: UNS

Spradley, J. P. (2007). Metode etnografi (edisi terjemahan oleh Mizbah Zulfa Elizabeth). Yogyakarta: Tiara Wacana

Subroto, D.E. (1992). Pengantar metoda penelitian linguistik struktural. Surakarta: Sebelas Maret University Press.

Suhardi. (2008). Sintaksis: Sebuah Sudut Pandang yang Komprehensif. Yogyakarta: UNY Press.

Sutopo, H. B. (2002). Metodologi penelitian kualitatif: dasar teori dan terapannya dalam penelitian. Surakarta: Universitas Sebelas Maret.

Sutopo, H. B. (2006). Penelitian kualitatif: dasar teori dan terapannya dalam penelitian. Surakarta: Universitas Sebelas Maret.

Supana. (2012). Kajian terjemahan penanda kohesi pada novel 'Wings' karya Danielle Steel ke dalam Bahasa Indonesia. Disertasi. Surakarta: UNS.

Suryawinata, Z., \& Hariyanto, S. (2003). Translation: bahasan teori \& penuntun praktis menerjemahkan. Yogyakarta: Kanisius. 